\title{
Visual Application Pawukon On Wall Lamp
}

\author{
Anung B. Studyanto ${ }^{1}$, Setyawan ${ }^{2}$, Rahmanu Widayat ${ }^{3}$ \\ ${ }^{1}$ Department of Interior Design, Faculty of Arts and Design, Sebelas Maret University, Indonesia \\ ${ }^{2}$ Department of Crafts/Textile, Faculty of Arts and Design, Sebelas Maret University, Indonesia \\ ${ }^{3}$ Department of Interior Design, Faculty of Arts and Design, Sebelas Maret University, Indonesia \\ 1anungbs@staff.uns.ac.id, 22setyawan@staff.uns.ac.id, \\ ${ }^{3}$ rahmanuwidayat@staff.uns.ac.id
}

\begin{abstract}
The presence of Pawukon as a Javanese calendar system is unpopular among Javanese themselves compared to the Chinese cap ji shio or the zodiac from the West, which is problematic. Pawukon in primbon books contains predictions about the time calculation system. These books are not only owned by most people but also live within the palace. It is necessary to preserve Pawukon through various media. This article is the result of research in Visual Exploration of Pawukon for the Development of Decorative Lighting Design as an Aesthetic Interior Element, a study of research and development, to explore the visual richness of the Islamic Mataram era in Pawukon form as a decorative lighting product. Visual Pawukon exploration results are used to develop decorative lighting designs into innovative, competitive and aesthetically pleasing interior elements while preserving Pawukon and providing innovation for the development of decorative lighting designs. As one of the preservation media, the application of Pawukon in developing decorative lighting designs is expected to be more accepted by various groups.
\end{abstract}

Keyword: application, visual, Pawukon, decorative ligting, wall lamp

\section{INTRODUCTION}

Pawukon, outside of belief, has a beauty value inherited from Javanese ancestors. For a long time, Pawukon has been developing in Java, according to Prof. Dr. Philip Van Akkeren, a researcher from the Netherlands, explains that pawukon traces can be retrieved to the 10th century, written on stone and brass or bronze plaques with ancient Javanese letters. The charter reports on the use of the Javanese prey-predator chain in the form of astrology and Javanese pawukon alongside calendars originating from India. At that time, Pawukon was already used among kingdoms and even rural communities in Java had used it long before that $[1]$.

Pawukon includes aesthetic elements that are unpopular among the current generation. The visual of pawukon as one of the fascinating cultural heritages is the Javanese calendar system or pethangan based on Hindu mythology regarding the time associated with the prediction of human life based on wuku (7 days calculation). There are 30 pictures of pawukon, from the picture of wuku Sinta to picture of wuku Watugunung with pictures of gods 
or goddesses. The shape is like wayang purwa (first form of puppetry) equipped with pictures of buildings or gedhong, weapons, various types of trees, birds, and others. Each of these elements has a specific purpose and meaning. The composition of the various elements makes the overall shape very interesting.

Pawukon contains predictions about the calculation of time contained in primbon book. These books are not only owned by most people but also live within the palace. For instance, in Surakarta palace, there are primbon that contain mystics, matters related to beliefs, such as amulets, prayers, information about fortunate events, destiny, omen, dream interpretation, predictions and so on [2]. Another example in the Yogyakarta Palace is that primbon containing certain days and dates that are considered more suitable than other days for marriage, long trips, building houses and so on. Primbon also contains pawukon in visual form, which is named pawukon picture and is given decoration in the form of puppets [3]. Pawukon picture also developed among the aristocracy of ancient community systems outside the palace, such as Semarang regent Adipati Sura Adimenggala (1765-1839) who served as regent from 1809 to 1822. Adipati Sura Adimenggala had made pawukon entitled Papakem Watugunung, along with other Javanese scripts were given to Rafles, Crawfurd, and Mackenzie (British officials) to help them learn history and culture [3].

\section{METHODS}

The initial visual exploration data is a form of Pawukon from Primbon book, which is then redrawn to be the source in Pawukon visual exploration. Data analysis used an interactive analysis model with three components: data reduction, data presentation, and drawing conclusions or verification. In this study, the data for data reduction is from pawukon images, data display from pawukon images, and drawing conclusions from pawukon images. These activities were conducted in an interactive form through the process of collecting data as a cyclical process. In the implementation process, the researcher moves between the components of analysis with the data collection while the data collection process is still ongoing [4]. The method used is studying the visual and artistic potential of Pawukon to be developed into an interior aesthetic element that is easily accepted by various groups. The next stage is the creation of various wall lamps designs by applying visual Pawukon as the main element.

\section{RESULT AND DISCUSSION}

Pawukon visual exploration by exploring the discourse in it and examining the visual and artistic potential so it can be developed into an aesthetic element that is appropriate to the present context. The creation of decorative lighting design with visual exploration of Pawukon can be performed into various types, for instance, wall lamps designs. The first step is to redraw Pawukon. Pawukon arts is processed from images by R.M. Soelardi who actively drew puppets from 1930-1960 and was found in the book "Pawukon 3000". The method used is the Ngowahi Rupa concept or transformation from paper to copper. It is expected that a new and more appropriate nuance will be present when applied to the interior. 
Visual Pawukon is applied to wall lamp designs with various techniques and materials, based on consideration of effectiveness and efficiency in its manufacture. Application techniques of Pawukon on wall lamp are performed with mudul technique and glass painting technique. While the material exploration on these wall lights is copper and acrylic plates because the material is durable and looks luxurious compared to paper.

The mudul technique on the copper/brass plate is made on jabung to produce a concaveconvex effect, arranged by a krawangan (translucent) technique. Mudul is a technique for making motifs on copper waste originating from word dimudul or ditotok (renewed) [5].
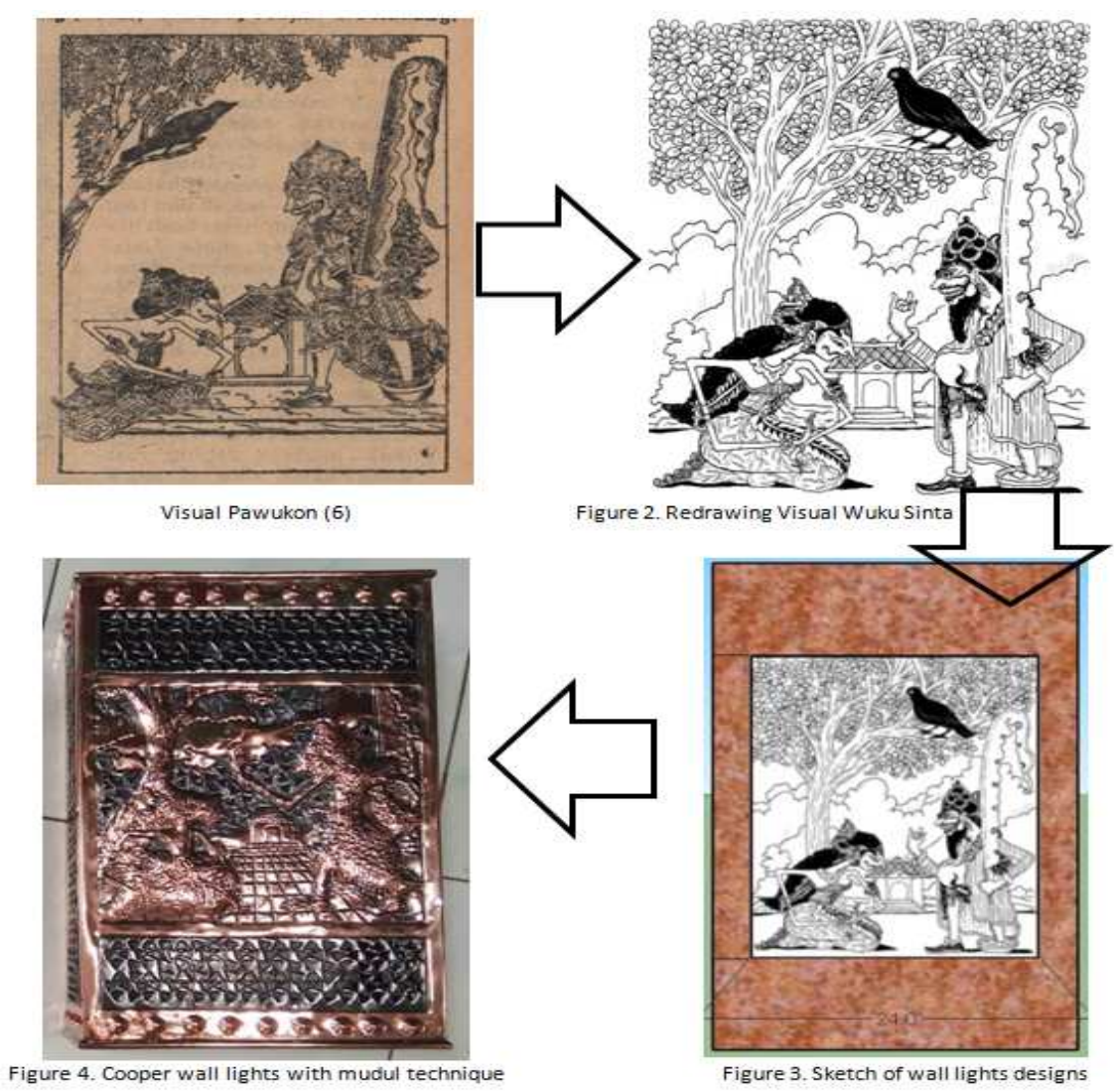

Wall lamp with the application of Pawukon processing with copper plate material

The application of the technique of glass painting by transferring the visual appearance of the Pawukon to Acrylic media, the contour [outline] is made continuously so it can be filled in color with transparent paint. Depicting the visual appearance contour of Pawukon on Acrylic with prada, using canting (pen-like instrument) as well as in batik technique. To assemble into a wall lamp, it requires a framework (in this case using a combination of Dutch Teak and Mahogany). 

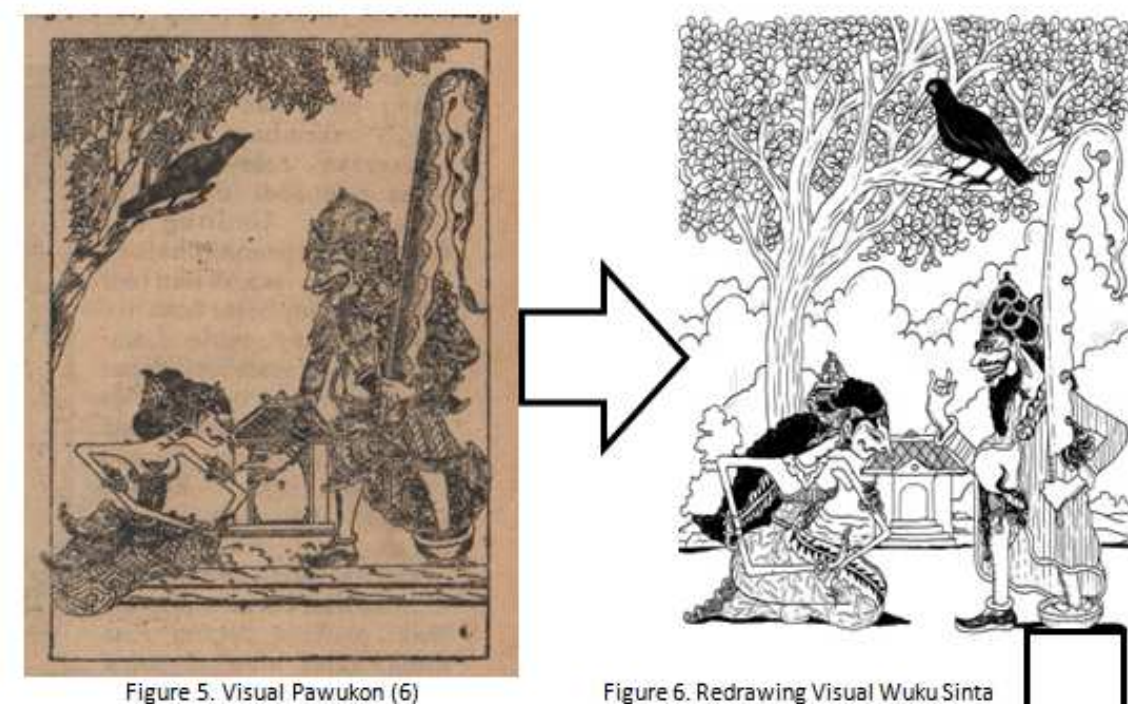

Figure 5. Visual Pawukon (6)

Figure 6. Redrawing Visual Wuku Sinta
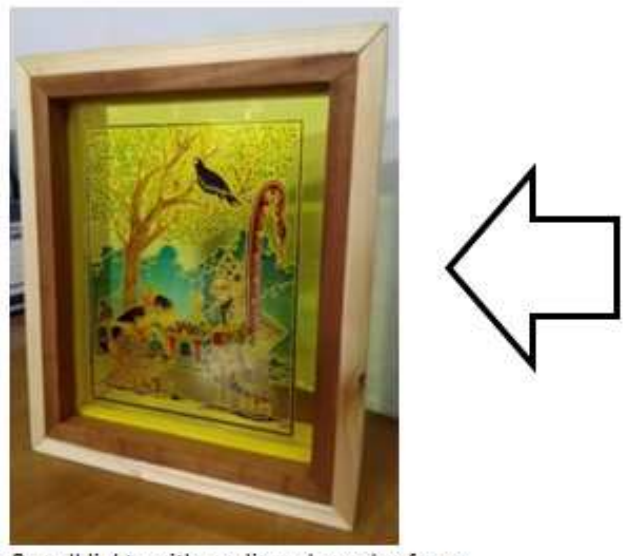

Figure 8 . wall lights with acrylic and wooden frame

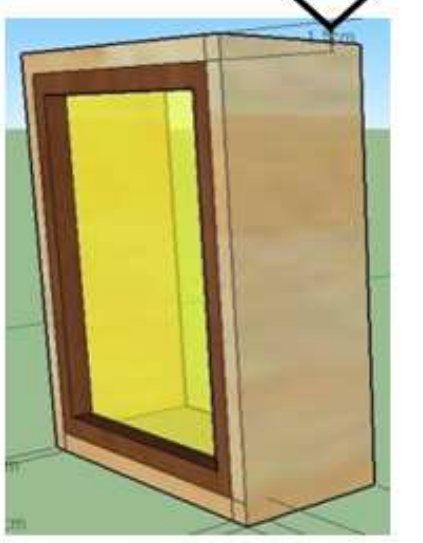

Figure 7. Sketch of wall lights designs

Wall light with the application of the visual Pawukon with acrylic painting and wooden frame

The physical environment in buildings and public spaces are media (facilities) to accommodate the activities that apply to the public. This obviously requires the applied consequences of physical space-building facilities which are universal, or inclusive; these are the physical space-building facilities that could be used by everyone as civitas-space buildings. Physical space-building facilities with a universal approach (inclusive) as a consequence of these public space buildings have not become commonly applied in Indonesia. Many of the physical space building designs that are mostly applied have not considered the needs of the certain sides that have physical limitations, the range of certain age, and also the difference between the sexes equally[6][7]. 
The light source on the wall lights is behind the Pawukon so it can provide the clarity effect of the visual Pawukon. Existing light transparency raises decorative aspects[8]. The application of pawukon images in interior design places more emphasis on the presence of the Javanese atmosphere, especially the interiors built nowadays. Pawukon images present in hotel interiors (lobbies, restaurants, meeting rooms and bedrooms) with Javanese themes. This is a deepening and development of interior designers to present Javanese cultural artifacts as an aesthetic element that has been forgotten by the current generation [9][10] [11].

\section{CONCLUSION}

Given the development of the design of wall lamp with copper base materials, it has evolved to explore with other materials. The consideration is based on the effectiveness and efficiency in its manufacture, as well as flexibility in exploring visual considerations. The use of Acrylic, Wood and Iron materials as materials is an alternative to the development of wall lights designs. Pawukon visual exploration results are used to develop decorative lighting designs into innovative, competitive, aesthetic interior elements. Visual exploration of the visual pawukon into the design of lamps can bring Javanese nuances to the interior design, in addition to providing innovation for the development of decorative lighting designs, aside from being a media for the preservation of past cultural heritage. The application of Pawukon in developing decorative lighting designs is expected to be more easily accepted by various groups.

\section{REFERENCES}

[1] Sindhunata, Hermanu. Pawukon. Yogyakarta: Bentara Budaya; 2003.

[2] Suratman D. Kehidupan Dunia Kraton Surakarta 1830 - 1939. Yogyakarta: Penerbit Taman Siswa; 1989.

[3] Tim Penyusun. Katalog Surat Emas Budaya Tulis Indonesia. Jakarta: Yayasan Lontar; 1991.

[4] Sutopo H. Metode Penelitian Kualitatif. Surakarta: Sebelas Maret University Press; 2002.

[5] Studyanto AB, Widayat R. "Pengembangan Desain Decorative Lighting dengan Memanfaatkan Limbah Metal pada Sentra Industri Kerajinan Tembaga/Kuningan di Desa Tumang". In Seminar Nasional-Pengabdian kepada Masyarakat. Jakarta: Fakultas Seni Rupa dan Desain Universitas Trisakti. 2016.

[6] Tanoyo R. Primbon Pawukon. Solo: Sadu Budi; 1983.

[7] Kuijsters A, Redi J, De Ruyter B, Heynderickx I. Lighting to make you feel better: Improving the mood of elderly people with affective ambiences. PLoS One 10(7). 2015

[8] Kusumarini, Y., de Yong, S., \& Thamrin, D. Signage System of Malls in Surabaya: Universal interior design applications and suggestions for solution. Procedia-Social and Behavioral Sciences, 68, pp.515-525. 2012.

[9] Widayat R. Wangun Visual Concept In Pawukon Figures And Interior Design Contexts. Mudra JURNAL Seni Budaya 33(3). 2018.

[10] Widayat, Rahmanu and Studyanto, Anung B. Exploration of Design Development Borobudur Chair with The Aèng Method (strange), Proceedings of the 4th Bandung Creative Movement International Conference on Creative Industries 2017 (4th BCM 2017), Amsterdam: Atlantis Press. 2018. 
[11] K. Saddhono, "Cultural and Social Change of Foreign Students in Indonesia: The Influence of Javanese Culture in Teaching Indonesian to Speakers of Other Languages (TISOL)," in IOP Conference Series: Earth and Environmental Science, 2018, vol. 126, no. 1 . 